\title{
From Dearth to El Dorado: Andean Nature, Plate Tectonics, and the Ontologies of Ecuadorian Resource Wealth
}

\author{
DAVID KNEAS \\ UNIVERSITY OF SOUTH CAROLINA
}

\begin{abstract}
Since the early 1990s, the Ecuadorian government has pledged to convert the nation into a "mining country" of global standing. Contemporary claims of mineral wealth, however, stand in stark contrast to previous assessments. Indeed, through much of the $20^{\text {m }}$ century, geologists described Ecuador as a country of mineral dearth. Exploring the process through which Ecuador seemingly transitioned from a nation of resource scarcity to one of mineral plenty, I demonstrate how assessments of Ecuador's resource potential relate to ideas of Andean nature. Promoters of resource abundance have emphasized Andean uniformity and equivalence-the notion that Ecuador's mineral wealth is inevitable by virtue of the resource richness of its Andean neighbors. Geologists who have questioned Ecuador's mineral content, on the other hand, have emphasized Andean heterogeneity. In the recent promotion of Ecuador's resource potential, notions of Andean uniformity have been bolstered by models of subsoil copper that emerged in the in 1970s in the context of plate-tectonic theory. In highlighting the linkage between ideas of Andean nature and appraisals of Ecuadorian resource potential since the late 19 century, I outline the dialectics between nature and natural resources that underpin processes of resource becoming.
\end{abstract}

\section{Keywords}

mineral resources; nature; Andes; Ecuador; plate-tectonic theory

\section{Introduction}

Over the past three decades, the Ecuadorian government has promised to make the nation a "mining country" of global significance. In 1988, Ecuador's Undersecretary of Mines confidently stated that "Ecuador has initiated its mining development." ${ }_{2}$ In the context of neo-liberal reforms to the nation's mining laws the World Bank endorsed this assertion, stating in 1993 that mining

\footnotetext{
David Kneas, Email: kneas@mailbox.sc.edu

„ "Ecuador inicio su desarollo minero." Mineria Ecuatoriana (July 1988), p. 42.

Copyright (C) 2018 (David Kneas). Licensed under the Creative Commons Attribution Non-commercial No Derivatives (by-nc-nd). Available at estsjournal.org.
} 
would be "a mainstay of Ecuador's economy for years to come" (World Bank 1993:18). Undeterred by a notable lack of successful exploration in the 1990s, Ecuadorian officials further revised the nation's mining laws at the turn of the millennium. Officials then proclaimed that, "The hour of mining has arrived." It didn't. In fact, in the context of both the 2007 election of President Rafael Correa, who began to retool mining legislation along nationalist lines, and a decline in global commodity prices, mineral exploration in Ecuador stopped almost entirely. Though facing strong headwinds of depressed commodity prices, Correa reaffirmed a temporal horizon of mineral extraction, declaring in 2012 that Ecuador would soon "pass into a new era, the era of mining."s

Despite the repeated series of "false dawns" over the past three decades, officials continue to forecast a future of large-scale mining. Optimism is currently high. With rising commodity prices over the past few years, especially for copper, and modifications to Ecuador's mining laws that lessen the nationalist stakes, investment and exploration in Ecuador are on the rise. The continued invocation of an incipient mining boom is premised upon the notion that Ecuador is a country of inherent mineral wealth. As Ecuador's Minister of Mines stated bluntly in 2000, "Ecuador has immense mining potential." This largely reiterates language used since the 1990s that Ecuador's mineral resources extended "the length and width of the country.". It likewise parallels the recurrent assertion through the 1990s that "The Country of El Dorado is not a Myth." Promotional materials published in 2008 by Correa's government claimed that Ecuador has more copper than Chile.s Alongside the pronouncement that the nation is on the cusp of a transformative shift towards metallic mining is the contention that Ecuador is simultaneously unexplored. Ecuador's Minister of Mines stated in 2001 that, unlike its Andean neighbors, Ecuador's subsoil resources "have largely gone unexplored." Most recently, at the 2016 and 2017 Ecuador session of the world's largest mining conference, PDAC (Prospectors and Development Association of Canada), the Ecuadorian delegation repeatedly emphasized that Ecuador was over "90\% unexplored."

Though Ecuadorian officials have continually promoted the nation as one of untapped and unexplored resource abundance, contemporary claims of mineral plenty stand in stark contrast to previous assessments of mineral dearth. Indeed, through much of the $20^{\text {in }}$ century, geologists portrayed Ecuador as a nation of mineral scarcity. US geologist W.C. Stoll synthesized these arguments in the flagship journal Economic Geology in 1962, stating that, "There is little present evidence that Ecuador will ever be an important mining country" (1962:800). These

3 A 1994 promotional feature from Ecuador's mining ministry titled, "Mining: the Future of Ecuador," reinforced this sense of mining inevitability. "Mineria: Futuro del Ecuador." Mineria Ecuatoriana (April 1994), p. 3.

" "Llego la hora de la Mineria en el Ecuador." Mineria Ecuatoriana (October 2000), p. 3

s "Ecuador apuesta su crecimiento a la minería a gran escala." El Pais (12 January, 2012).

- Mineria Ecuatoriana (February 1990), p. 7; Mineria Ecuatoriana (April 1994), p. 1.

- For example, Mineria Ecuatoriana (April 1994), p. 63.

" "Ley Minera: Prosperidad y armonía para La Patria." Ecuador: Secretaría de los Pueblos, Movimientos Sociales, y Participación Ciudadana (No. 15).

" "Ecuador: Andean Opportunities Await Evaluation," Special Supplement in The Mining Journal (November 2001), 1-12. 
geologists did not deny the possibility of mineral discovery, but based their appraisals of doubt in opposition to the assumptions of resource abundance that dominated the $19^{\text {in }}$ and early $20^{\text {th }}$ century narratives of Ecuador by geographers, travel writers, and naturalists.

In this article, I explore the frameworks of knowledge and nature that underpin the varied assessments of Ecuador's resource potential since the late 19 century, with a focus on the nation's seeming transition from a country of mineral dearth to one of El Dorado in the late 20 century..$^{10}$ As I demonstrate, contrasting accounts of Ecuador's subsoil potential are informed by divergent understandings of the Andes and the underlying essence of Andean nature. "The Andes," I reveal, comprise one of the primary ways Ecuador's subsoil resources are known and imagined. Building on Katherine Jones' work, I approach the scale of the Andes, not as a natural "structure which 'exists,' but as an epistemological one-a way of knowing or apprehending" (Jones 1997:28). Promoters of Ecuador's resource potential, in the late 19 century as well as the late 20", framed their arguments with an image of Andean uniformity and equivalence- that the Andes are not only inherently rich in mineral resources, but largely uniform and homogenous from Chile to Colombia. Mid-20" century geologists, on the other hand, questioned Ecuador's resource potential by emphasizing Andean heterogeneity-that the nature of the Andes is highly variable, with an irregular distribution of minerals.

Recent articulations of Ecuadorian resource wealth also reflect shifts in geological theory, specifically developments in plate tectonics, which have bolstered notions of Andean uniformity. The case of copper is significant here. While Ecuador's promotion of mining includes elements like gold and silver, the prospect of large-scale copper mining plays an outsized role in the specter of Ecuador as a mining country of global standing. Through the 1970s, economic geologists incorporated plate tectonics to describe the origin and distribution of subsoil copper. In outlining copper mineralization in relation to the subduction of oceanic plates, these geologists presented a simplified, yet powerful, image of Andean uniformity. These models indicated a common origin story for copper mines from Chile to as far north as British Columbia, instilling a degree of expectation for areas in between, including Ecuador. Such advances in geological research have played a prominent role, in particular, for the junior exploration companies who have worked in Ecuador. Junior companies, who depend on investments garnered in sites like the Toronto Stock Exchange, routinely spin their exploration programs to maximize resource potential (Tsing 2000; Kneas 2016). Their promotional language easily oscillates between iterations of the "Andean copper belt" and technical language of subsoil geology that is derived from plate-tectonic models of copper formation.

Far from being natural entities that await discovery and extraction, natural resources come into being through shifting configurations of social and material relations (Richardson and Weszkalnys 2014; Walsh 2010; Ferry 2005; Frederiksen 2013). In refocusing analysis away from what is natural about natural resources, recent scholarship centered on "resource becoming" has brought to the fore debates about resource ontology-questions about what constitutes the

${ }^{10}$ This research stems from a critical reading of published works on Ecuador from the late $19^{\text {th }}$ century as well as archival research in Ecuador, the US National Archives, and the archives of the British Geological Survey. 
essence and matter of natural resources and through what forms of analysis we should study their articulations (Graeber 2015:15). For Gavin Bridge, resources are really cultural categories "into which societies place those components of the non-human world that are considered useful or valuable in some way" (Bridge 2009:1219). Scholars continue to highlight aspects of this argument, that resources and resource estimations are cultural and social before they are natural and physical (Bowden 1985; Tsing 2000; Hughes 2017; Kneas 2017). In the context of broader theories and debates about materiality, scholars have also examined the diverse properties and agencies of specific natural resources (Bennett 2010; Kaup 2008). Thus, while research continually locates processes of resource becoming in relation to social and political dynamics, frameworks of resource materiality also underscore how the settings, dimensions, and life-cycles of resources matter in the ways we study and theorize resource making.

Given the variation of what counts as a natural resource (diamonds, gold, oil, copper, coal), the distinct processes of resource extraction, and the cultural frameworks in which these resources circulate, recent overviews of resource becoming have tended to shift questions of ontology away from broad, abstract conceptualizations into more specific and situated forms of historical and ethnographic analysis. In their seminal outline of the anthropology of resource materiality, Richardson and Weszkalnys (2014) emphasize the connections between ontology and historicity-the underlying histories, processes, and assemblages that make particular iterations of resource potential possible. Bakker and Bridge (2006) likewise broach ontological questions through language of specific resource topologies, relational processes, and situated histories, while Chelsea Chapman (2013) analyzes "the multiple ontological footings on which accounts of oil make sense and are acted upon as truths" (2013:105).

This article builds on these insights that, in essence, put ontological questions into historical motion. For Ann Stoler, pursuing historical ontology requires "identification of mutating assignments of essence and its predicates in specific time and place" (Stoler 2009:4). As I describe here, notions of Ecuadorian resource abundance rely on and substantiate certain perceptions of Andean nature over others-ideas of uniformity and equivalence over Andean difference and hetereogentity. In other words, the becoming of Ecuadorian resource potential is directly linked to mutating ontologies of Andean essence occasioned by plate-tectonic theory, the reiteration of $19^{\text {" }}$ century notions of abundance, and its crude articulation within the era of neoliberal mining reform and investment.

In linking questions of resource becoming in Ecuador with the intellectual and cultural history of the Andes, I emphasize the ongoing dialectics of nature within processes of resource becoming. Resource emergence entails abstracting and conceptually separating out elements of social and economic value. Jim Scott's description of legibility and simplification, of bringing "into sharp focus certain limited aspects of an otherwise far more complex and unwieldy reality" (Scott 1998:11), is an apt rendering of this process. Though recent theorizations are attuned to the non-linearity of specific resources, the prevailing ways we think about the stages of resource becoming are still premised on boundary making and temporal separation, between elements of value from milieus of nature (Bridge 2001). This teleology parallels academic research in which "natural resources" emerges from and displaces "nature" as an object of analytical attention. 
Indeed, scholarship on resource materiality is often defined by an acute focus on specific materials, their properties, textures, and agentive capacities (Mitchell 2009; Barry 2013). In outlining the relationship between ideas of Andean nature and Ecuador's resource potential, however, I demonstrate how the becoming of natural resources does not leave nature behind, but continually draws on and enlists it in a dialectical process. As I detail in this article, the underlying arguments of Andean nature inscribed by plate-tectonic models of subsoil copper parallel those put forward in landscape paintings of the late $19^{\text {in }}$ century. The significance of Ecuador's particular sites of mineral extraction have always been indexed and measured against different iterations of Andean essence. Furthermore, impressions of Andean uniformity have underpinned the continual renewal of Ecuadorian mineral exploration over the past three decades, providing a foundation of truth against which resource exploration makes sense.

In the first section of the paper, I examine the specter of Andean uniformity within current promotions of mineral wealth in Ecuador and trace its links to $19^{\text {th }}$ century modes of travel writing and landscape painting. I then examine how Andean uniformity shaped the ways $19^{\text {th }}$ and early 20 century actors (US and European naturalists and geographers) understood and evaluated Ecuador's mining potential, including the ways these assessments accounted for the mining that was actually taking place in Ecuador during this period. In the second section of the paper, I detail chronicles of US-based geologists who dismissed Ecuador's mineral potential through the mid-20 century, and did so while explicitly writing against notions of Andean homogeneity. In their emphasis on Andean difference and heterogeneity, these opinions likewise based their evaluations on known mineral deposits and operations. In the paper's third section, I discuss how notions of Andean uniformity re-emerged in the context of plate-tectonic theory and early models of subsoil copper.

In drawing attention to the specter of the Andes within Ecuador's promotion of mining, I highlight, on the one hand, the ontological natures and epistemological scales that inform assumptions of resource potential. My analysis also reveals how large-scale imagery of Andean uniformity helps generate floating signifiers of resource potential. Like Levi-Strauss' (Mehlman 1972) notion of a signifier without a referent, I outline models of "the Andes" that constitute ideal types of Andean nature whose scale is simultaneously local and general, and everywhere and nowhere. The reference to El Dorado is a prime example. El Dorado is an image of a particular locality that defines an underlying essence of potential across a broad landscape. Embodied in sources as diverse as $19^{\text {i }}$ century landscape paintings and plate tectonic models of subsoil copper, these placeless referents, defined by a nowhere/everywhere dynamic, have played a recurring role in the articulation of Ecuador as a nation of "unexplored abundance." 


\section{Andean Uniformity, Past and Present}

As the image and phrase of "Andean opportunities" (Fig.1) reveals, ideas of Andean uniformity have played a prominent role in Ecuador's promotion of mining." The adjective "Andean" is less about the particular peak of the Cotopaxi volcano, but more about the mineral resources associated with the Andean range, which those iconic, snow-capped peaks have long signified (Poole 1998; Pratt 1993). Indeed, the image of Ecuador's Cotopoxi volcano epitomizes how placeless referents come to represent mineral potential. There are not, nor have there ever been claims that the immediate terrain of Cotopaxi contains or harbors abundant mineral resources. As I discuss below, in the 1940s, a small outfit called the Cotopaxi Exploration Company actually mined copper in the same province as the Cotopaxi volcano, but the results of that endeavor were underwhelming. This image, in other words, is not about Cotopaxi, but the way Cotopaxi symbolizes a wider, more abstract, impression of Andean resource wealth.
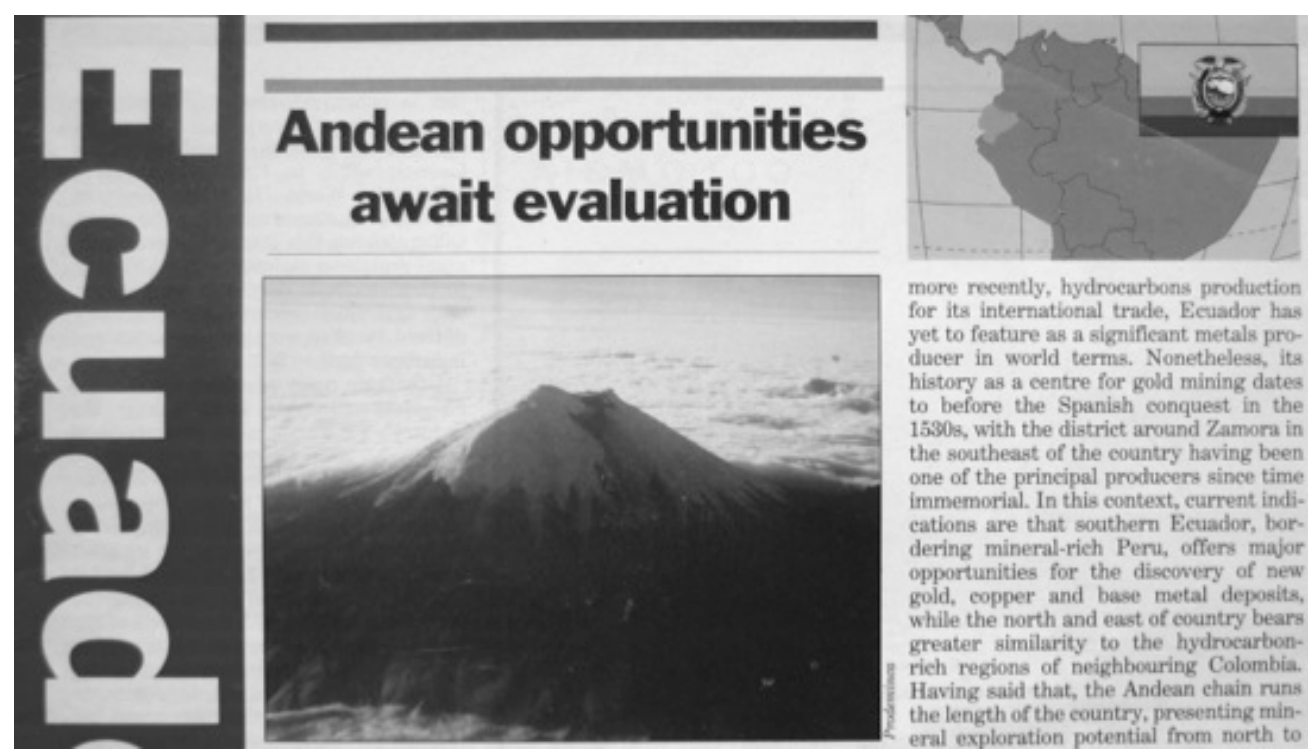

more recently, hydrocarbons production for its international trade, Eeuador has yet to feature as a significant metals producer in world terms. Nonetheless, its history as a centre for gold mining dates to before the Spaniah conquest in the 1530 s, with the district around 7 amera in the soatheast of the country having been the southeast of the country having been one of the principal producers since time immemorial. In this context, current indications are that southern Eeuador, bordering mineral-rich Peru, offers major opportunities for the discovery of new gold, copper and base metal deposits, while the north and east of country bears greater gimilarity to the hydrocarbonrich regions of neighbeuring Colombis. Hasing said that, the Andean chain runs Having said that, the Andean chain runs the length of the country, presenting min:-
eral exploration potential from north to

Figure 1: “Andean Opportunities” Promotional supplement from The Mining Journal (2001)

Less Ecuador's Andean-ness be in doubt, the first line of the text from a 2001 promotional supplement in the industry journal The Northern Miner reiterates Ecuador's Andean position: “Despite being one of South America's smaller countries, Ecuador's geographical setting provides it with mineral potential that bears credible similarities to that of its neighbors to both

" "Ecuador: Andean Opportunities Await Evaluation." Special Supplement in The Mining Journal (November 2001), 1-12. 
north and south." " Mining in Ecuador has never had the stature it has in other Andean republics, namely Peru, Bolivia, and Chile. Nevertheless, Ecuador's Andean-ness has been one of the key organizing logics in the promotion of mining since the early 1990s. In this logic, "the Andes" are much more than a geographical reference. They are the natural given against which truth claims of Ecuador's mineral potential are made. ${ }^{1}$ In this rhetoric, the question of whether or not Ecuador has mineral resources has, in essence, already been answered. "The Andes" are rich in minerals, so exploration in Ecuador is more a question of where those minerals are located than a question of whether those minerals are there to begin with. As Ecuador's Minister of Mines stated in The Northern Miner article: "It is only a matter of time, because the legal framework is there, the economic framework is there, and the potential is there. Chile, Peru, and even Colombia all have a lot of mines, so it would be silly to argue that Ecuador does not have the same potential. The border does not stop the geology." "As officials in the 1990s and mid-2000s likewise argued in relation to other mineral sites in the Andes, "Ecuador cannot be the exception."

The sense of "the Andes" evoked in the imagery above is one that posits the Andes as a timeless feature of South American geography. Despite its seeming natural-ness, however, the idea of the Andes is a $19^{\text {ti }}$ century post-colonial construction. The colonial cartography of the Spanish empire, for example, did not center South America around the notion of an Andean backbone. Highly textual and descriptive, the Spanish described and depicted particular mountains, but valley lands interspersed them, undercutting a sense of connectedness or Andean uniformity. Indeed, the term "Andes," when it did feature in Spanish accounts, referenced hot, wet forested terrains towards the Amazon basin (Orlove 1993). As a variety of scholars have outlined (Poole 1997; Stepan 2001), the creation of the Andes as a social fact through the 19 century stemmed, in part, from the work of Alexander von Humboldt, whose visual discourse of knowledge helped set the stage for the reinvention of South America through the medium of nature and the ordering of South American space around the iconic triad of Andes, Amazon, and Plain (Pratt 1993:123). In the context of European and North American imperial expansion, this geographical construction of the Andes invited outside exploration and investment, naturalizing South American nations within the sphere of US informal empire. ${ }^{16}$

Emblematic of the cultural construction of the Andes furthered by a variety of European and North American travel writers, naturalists, and geographers is the iconic Heart of the Andes, painted by landscape artist Frederick Edwin Church in 1859. Heart of the Andes (Fig. 2) circulated widely in the United States and embodied a recurring discourse of South American nature found throughout 19 ${ }^{\text {in }}$ century US and European public culture. Heart of the Andes was not just a

\footnotetext{
12 "Explore Ecuador," Special Supplement to The Northern Miner (November 2001), p. 1.

${ }^{13}$ As Ecuador's Minister of Energy and Mines stated in 1994: “Ecuador's geology is similar to Chile, Peru, and Bolivia, lands known for their great mineral wealth; our colonial mining history, along with signs we have from all over the country, clearly indicate that the mining potential of the country is very great and practically intact." "Mineria: Futuro del Ecuador." Mineria Ecuatoriana (April 1994), p. 3.

${ }_{14}$ "Explore Ecuador," Special Supplement to The Northern Miner (November 2001), p. 8.

${ }^{15}$ Mineria 41 (2005), p. 22.

${ }_{16}$ The articulation of the Andes also helped anchor the state-making narratives of Andean republics, making national space more legible along distinct hierarchies of race and difference (Orlove 1993).
} 
representation of highland South America, but a key part of the visual mediums through which the region was known and imagined, influencing "how people residing in the United States perceived, represented, and acted on the region of western South America known as 'the Andes'" (Poole 1998:108).

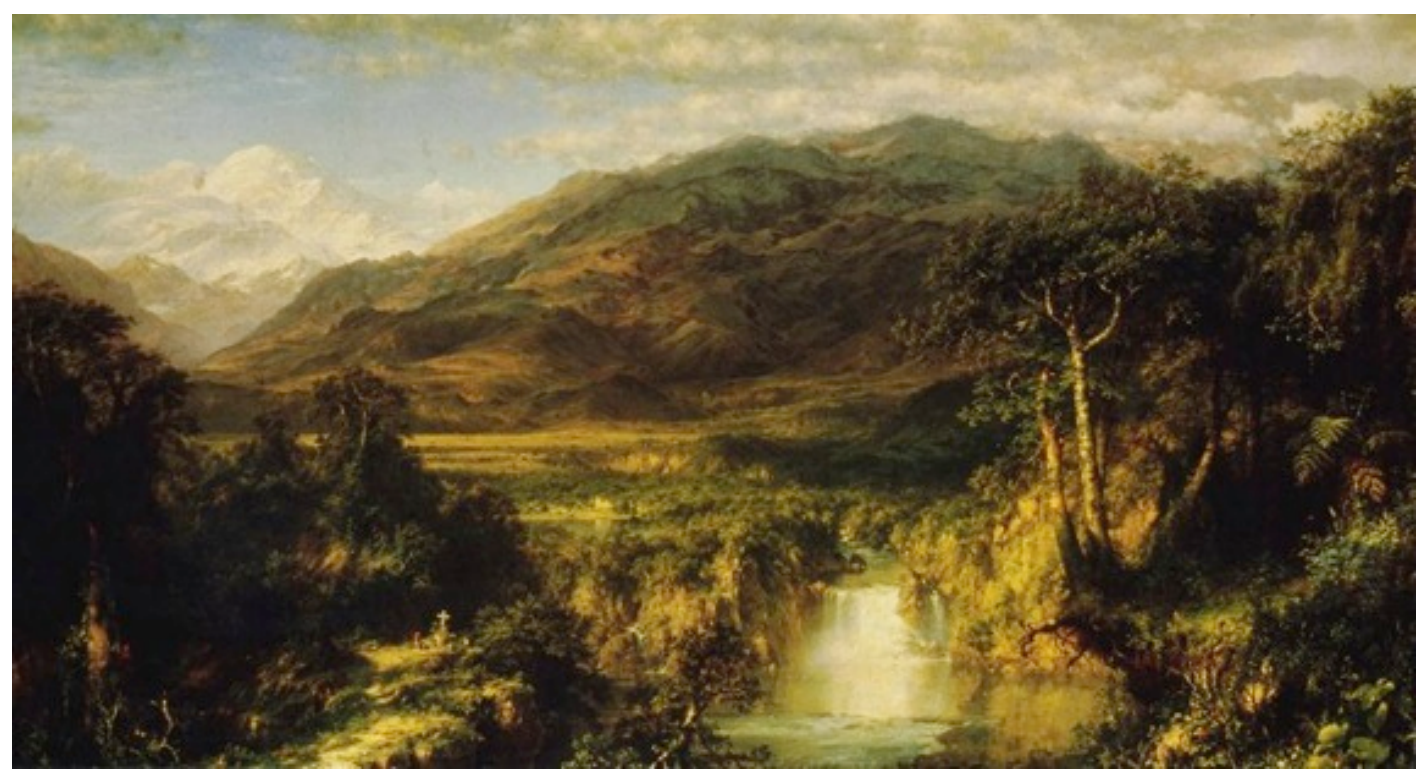

Figure 2: Heart of the Andes (Yale University Digital Collection, 1859)

Heart of the Andes was not a particular landscape, but rather a compilation of an essentialized model of Andean nature. As the companion guide to the painting acknowledged, "Mr. Church has condensed the condensation of nature. It is not an actual scene, but the subtle essence of many scenes combined into a typical picture... all earth's riches compacted into one many-sided crystal" (Winthrop 1859:12). What interests me in Church's painting is the underlying notion of Andean equivalence that it entails and reproduces: that the Andes depicted in one location is representative of Andean nature throughout. The "heart" in Church's Heart of the Andes is not about heart as geographical center and more about heart as essence, crux, or marrow. A discourse about the underlying essence of Andean terrains, Heart of the Andes is placeless. It exists nowhere in particular, while benchmarking an inherent truth of what specific Andean locations are or at least should be.

Impressions of Andean uniformity are ubiquitous within the "enterprise of knowledge" (Salvatore 1998) that defined European and North American representations of the Andes through the $19^{\text {i }}$ and early $20^{\text {i }}$ centuries. A representative example is US naturalist James Orton's 
1876 book The Andes and the Amazon; or Across the Continent of South America. In his text, Orton describes the geological rise of the Andean range as proceeding "uniformly and without interruption" (1876:115). Now, Orton says, "the Andes stand complete in their present gigantic proportions, one of the grandest and most symmetrical mountain chains in the world" (1876:117). Here, Orton is arguing that while the Andes cannot match the Himalayas in terms of absolute height, Andean uniformity and consistency more than make up for that difference: "Nowhere else does Nature present such a continuous and lofty chain of mountains, unbroken for eight thousand miles...nowhere in the Old World do we see a single well-defined mountain chain" (1876:117). For Orton and other US based naturalists of the late 19" century, Andean grandeur was defined by "symmetry" and "unbroken-ness."

The underlying truth of Andean uniformity, as encapsulated in Heart of the Andes, played a direct role in how $19^{\text {in }}$ and early $20^{\text {" }}$ century geographers and naturalists described Ecuador's mineral prospects. In an account of Ecuador's mining industry in 1860, for example, an English geographer admits that the nation has little evidence of identifiable mineral deposits (Pritchett 1860). Nevertheless, he assumes that such resources exist simply because of Ecuador's position in the Andes:

All that can at present be said of this branch of [mineral] wealth is that the Cordilleras of [Ecuador's] neighbors on the north and south have been proved by experience to be rich in silver and copper ores, which have been extensively worked. And surely the inference may be drawn, that this torpid and road-less country is as capable of a prosperous development as any on the Pacific shore (Pritchett 1860:74-75).

A similar framework is evident in a 1900 assessment of Ecuador's mineral industry by W.G. Higgens (1900). While Higgens also cites the lack of roads as a key obstacle to mineral development, he still sees promise for Ecuador's mining industry because of the nation's Andean location. "The uninterrupted belt of porphyries which runs along the chain of the Andes," Higgens states matter-of-factly, "is seamed with metalliferous veins" (1900:515). The critical variable for Higgens is "uninterrupted," stated with an obviousness that reflects how Andean uniformity and wealth structured nearly all descriptions of Ecuador's mineral potential during this period.

\section{Situating Knowledge}

The extent to which ideas of Andean nature framed accounts of Ecuador's mineral potential is especially striking in the context of the mining industry that did develop in the late $19^{\text {m }}$ century. Beginning in the 1880s, British investors re-opened gold mines that dated from the Spanish colonial period in southern Ecuador, around the town of Zaruma, on the southwestern slopes of the Andes. A company called the South American Development Corporation, which was based 
in New York City, took over the project in the late 1890s." SADCO, as the company became known in Ecuador, operated the Zaruma mining district until the early 1950s. The scale of SADCO's operations was significantly smaller than those in Peru and Chile. Nevertheless, the company was a large part of the economy of southern Ecuador and a key source of revenue for the national government."s

Contemporary promoters of mining in Ecuador refer to the country as "largely unexplored and practically intact." ". Far from being un-explored, however, there was an active period of mineral exploration through the first half of the $20^{\text {i }}$ century. Much of this was spearheaded by SADCO, but also included a number of individual geologists and small exploration companies. The Cotopaxi Exploration Company, created in the 1930s by SADCO, discovered and mined a deposit of copper in central Ecuador. The returns were modest, however. The mine only operated between 1939 and 1950, production that was buoyed by World War II and the resulting spike in copper prices. The company built a copper smelter in 1942 and constructed a road between the central Andes and the Ecuadorian coast. After they built a copper smelter, geologists from Cotopaxi explored surrounding areas of the western Andes to supply it, but "found nothing large enough to compensate for the high cost of road building and transportation" (Stoll 1962:805).

For many promoters of Ecuador's resource potential during this period (from late 19" into mid 20" centuries), Ecuador's existing mining industry did not factor directly into assessments of overall resource potential. Rather, reference to Andean nature and Andean symmetry overshadowed the nation's existing mining operations. The impression of Andean nature as the defining source of Ecuador's mineral wealth is evident in a 1920 article in the US based journal The South American:

It is absolutely certain that the extensive mountains that cross [Ecuador's] territory in all directions hide within their bosoms vast and rich deposits of gold, silver, copper, tin, lead and many more minerals. Besides this real mining district [Zaruma]... there is no doubt that throughout the vast territory of the republic there are minerals of many kinds. ${ }^{2 n}$

The divide between "real" mining districts and imagined "bosoms" that are both vast and rich was also the basis of 1916 arguments about Ecuador's mineral industry by JW Mercer, published in Mining and Engineering World and presented at the $2^{\text {nd }}$ Pan American Congress in Washington DC (Mercer 1919). For Mercer, himself a former SADCO geologist, the potential of Ecuador's

${ }_{17}$ This history is discussed in WC Stoll (1962).

${ }^{18}$ In the 1930s, for example, SADCO had over 1,500 direct employees while another 3,000 made their living indirectly from the mine. In other words, SADCO was "the life of commerce throughout all southern Ecuador." This information comes from: "Actions by Government of Ecuador injuriously affecting the rights of the South American Development Company, an American Corporation." Dayle McDonough (US Consul General, Guayaquil) to US State Department, 24 January 1938, National Archives Record Group 59 (RG 59 ), box 5690.

19 "Mineria: Futuro del Ecuador." Mineria Ecuatoriana (April 1994), p. 3

${ }_{20}$ "The Republic of Ecuador." (September 1920). The South American: A Journal For All Interested in Latin American Affairs 8(11), New York City. 
mining industry involves a totality that is distinct from the operations that he himself helped direct. Mercer began his assessment by saying that "it is difficult to write" about mining in Ecuador "when there is, in all of the republic, but one mining enterprise in actual operation, namely the gold mines in the southernmost Province" (Mercer 1919:202). Mercer insisted, nevertheless that, "there are many evidences of great mineral wealth." This evidence is not a catalogue of the extracted elements that Mercer might have been intimately familiar with, however. Rather, it is "the immense uplift of the Andes throughout the entire length of Ecuador that has furnished a vast area for the prospector" (Mercer 1919:202). In Mercer's estimation, Ecuador's existing mines do not count or factor into the frameworks of knowledge that would speak to the nation's resource potential and future as a mining country.

Mercer's dismissal of Ecuador's extracted minerals is not unique, but rather is a recurring component in Ecuador's promotion of mining. Recent scholarship across the intersection of STS and social movements has used the phrase "undone science" to highlight the processes and questions that should merit attention from health and environmental officials and experts but which are seldom addressed or asked (Hess 2016; Frickel and Kinchy 2015). Whereas this work highlights the science of material environments that goes undone, the process through which Mercer discounts Ecuador's material mining history exemplifies the undoing of both mineral histories and distinct artifacts of geological knowledge. In the continued invocation of Andean uniformity and symmetry, both Mercer and current promoters of resource potential disregard sites of both marginal resource presence or areas found to be lacking altogether. Such sites, like the copper mine worked in the 1940s by the Cotopaxi Exploration Company, present a point of specificity and friction that undermines ideal-type models of Andean abundance.

\section{II: Resource Scarcity and Andean Difference}

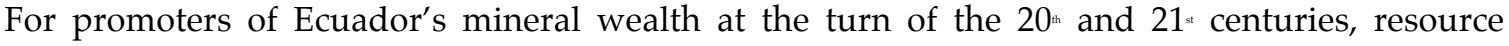
presence was and is a given, which can only be disproved, instead of the reverse. This shows the enduring imagery of Andean nature and associated expectations of resource potential. Yet while contemporary mineral discourse harkens back to the Andean nature espoused by Heart of the Andes, this discourse has not been consistent. Through much of the 20 century, in fact, many geologists argued the exact opposite- that Ecuador was scarce in mineral resources and had little chance of becoming a "mining country." This was especially true within the community of USbased geologists tasked to evaluate and comment on Ecuador's mining industry from WWI into the early 1960s. As I demonstrate below, not only did these geologists emphasize resource scarcity, but did so while refuting or arguing against ideas of Andean symmetry and inherent resource wealth.

These geologists had, to a certain extent, the luxury of doubt. In the wake of WWI, the US emerged as the dominant geo-political power in South America. Apart from large supplies of copper from the US southwest, US-based companies controlled the largest copper mines in Peru and Chile through the mid 1900s. To a degree, then, US based assessments of Ecuadorian minerals were guided by a more sober framework of resource potential, freed from the rhetorical 
excess that defined late $19^{\text {in }}$ century genres of travel writing and exploration. What interests me is how portrayals of resource scarcity are still indexed against notions of Andean nature, albeit one characterized by heterogeneity.

Traveling through the Andes as part of a USGS overseas geological survey after WWI, two US geologists described Ecuador as having a paucity of mineralization in their text The Mineral Deposits of South America, a general overview and survey of South American mining operations (Miller and Singewald: 1919). The title itself is noteworthy. Unlike the evocative character of 19" century exploration narratives, such as Orton's Along the Andes and Amazon, here we have a matter-of-fact title with little rhetorical flare. While these geologists do not discount the possibility of resource discovery in Ecuador, they are unimpressed by the existing evidence:

In the light of our present knowledge of the ore deposits of Ecuador, the unimportance of its mining industry must be ascribed primarily to the paucity of discovered mineralization. This is due in part to the fact that it does not seem to have been as highly favored in this respect as its neighbors on the south and on the north, and in part to the great mantle of fragmental volcanic material that covers so much of the northern portion of the Andean region and some of the southern half. But even in the southern half where this obstacle is not serious, mineralization seems to have been relatively weak, and this appears to be the real cause of the present status of the Ecuadorian mining industry. (Miller and Singewald 1919:412)

Apart from mineralization that is classified as "relatively weak" and characterized by its "paucity," what stands out in this statement is the phrase "our present knowledge." Unlike their contemporary, Mercer, these geologists limit their assessments of Ecuador's resource potential to the existing mining operations and known resource sites. They do not discount or ignore these mining locations in favor of an abstract Andean nature. Indeed, their comment about one nation being "favored" over another implies a randomness to-that is, an unequal distribution of -Andean mineral wealth. Furthermore, as if seeking to dispel $19^{\text {in }}$ century narratives of Andean uniformity, the authors of Mineral Deposits frame their text with the following comment on the Andes: "Although forming a continuous belt of elevated land, these mountains are, by no means, a unit. Instead they consist of several fairly distinct ranges, most of which have a north-south trend" (Miller and Singewald 1919:22).

The former head of the US Bureau of Mines and one of the founding members of the journal Economic Geology, H. Foster Bain, echoed these arguments in his 1934 text, Ores and Industries of South America, a title that shares the matter-of-fact sentiment of Mineral Deposits. Referring to Ecuador as "essentially an agricultural nation...[where] minerals have never been of much importance," Bain concludes that "[Ecuador] is not likely to become an important mineralproducing country" (Bain 1934:330). Although he does not differentiate the Andes like Mineral Deposits, Bain takes direct aim at popular myths of South American nature, writing that, "South America's age of gold and of silver lies in the past, not in its future" (Bain 1934:19). Bain's belittlement of South America stemmed from the desire to refute claims that the continent, increasingly seen in the inter-war period as the "land of the future," might overtake the United 
States in industrial development and power. The United States, Bain assures readers, need not worry, for the reality of South American nature falls well short of its mythical ideal. Writing from the position of an expert geologist, Bain summarizes: "It is clear from what has already been said that a belief that South America is a vast reservoir of untouched mineral wealth is wholly illusory" (Bain 1934:370).

In 1961, US Geologist George Ericksen traveled to Ecuador to determine if the United States should participate in geological mapping projects with the Ecuadorian government. Prior to his arrival in Ecuador, Ericksen had helped establish national geological surveys in Chile and Peru. Well versed in Andean geology and politics, Ericksen wanted nothing to do with Ecuador, insisting that "the possibility for discovery of numerous or large metalliferous deposits in Ecuador is remote." Like Bain and others, Ericksen also rejected visions of Andean uniformity. Drawing on "our accumulated [geological] knowledge," Ericksen outlined Andean mineralization as weakening from south to north, with resources becoming "progressively fewer" from central to northern Peru. "The northernmost mining district of any importance in Peru is about 400 Kilometers south of the Ecuadorian border," he wrote. In Ericksen's view, then, though the Andes may appear as a contiguous and homogenous mountain chain, the processes that produced mineral deposits were not themselves uniform. The uneven distribution of mineral deposits, Ericksen contends, bears this out. He did not reject the possibility of future resource discovery, but believed that "it is doubtful whether such deposits will be large or numerous."

While these mid-20" century commentators did note some potential for ongoing discoveries, they also argued that knowledge of Ecuador's resource potential was fairly complete. In relation to a US aid mission to Ecuador in 1941, Laurence Duggan, the State Department's Latin American Director, rejected the inclusion of mining in the US portfolio. Duggan said that it was his "understanding that the Geological Survey (USGS) had not looked with favor upon such an undertaking [mineral survey]...[as] the ground had already been pretty well examined by geologists from SADCO." Into the 1950s, Ecuador's small mining industry was waning. As the US State Department summarized in its 1958 economic review: "Mining in Ecuador is steadily declining in importance and plays an insignificant role in the economy. Known deposits of gold and silver are being exploited, but on a very small scale. Coal, iron, sulfur, copper, and other minerals are found in small deposits, but these deposits are not considered worthy of extensive exploitation." "Though these reports acknowledge that the discovery of "some heretofore unknown mineral deposit" was "within the realm of possibility," their overall message was: "it is unlikely that minerals can be of importance to Ecuador's economy." ${ }^{\prime s}$

Late $19^{\text {in }}$ and late 20 century resource boosters discounted, ignored, or marginalized existing mining operations in favor of more abstract notions of Andean wealth. Mid-20 century

"2 George Ericksen. "Geology in Ecuador: A Review” (1961). Center for Geological-Mining-Environmental Information (CIGMA). Ministry of Non-Renewable Resources (Quito, Ecuador). call number: GGE115.

${ }_{22}$ Ericksen, "Geology in Ecuador," p. 276.

${ }^{23}$ Duggan to Bonsal, 10 September 1941. RG 59, Box 4339. US National Archive

${ }_{24}$ US Embassy Annual Economic Assessment of Ecuador, April 1958. RG 59, Box 4254. US National Archive.

${ }_{25}$ US Embassy Annual Economic Assessment of Ecuador, April 1958. RG 59, Box 4254. 
geologists, on the other hand, emphasized the specificity of existing and known material resources. In doing so, they simultaneously reversed the underlying sense of Andean nature that indexed the meanings of these resources. Against the backdrop of Andean heterogeneity and difference, signifiers like Heart of the Andes have, in essence, fewer places to land. A noteworthy example of the focus on Ecuador's existing displays of mineral resources to assess the nation's overall potential comes from an Ecuadorian geologist writing in the 1930s, who observed that Ecuador is indeed rich, "but rich in poor mines." ${ }^{26}$ The concept of "rich in poor mines" is a direct reversal of models of uniform abundance. It draws attention to the fact that the mining operations that had emerged were not only of limited productivity, but were an order of magnitude smaller than resource production in Peru. "Rich in poor mines" also argues that such modest expectations should extend across the country.

\section{III: Plate Tectonics and Porphyry Copper}

In the early 1960s, the United Nations initiated a geological mapping project centered in southern Ecuador. The primary purpose of the program was to extend the life of the small-scale gold mining operations in this region. During the same period, US based Texaco began exploring for oil in the Ecuadorian Amazon. Oil exports began in the early 1970s as Ecuador became a founding member of OPEC and petroleum became the principle driver of the nation's economy. Although the UN project evolved into a geological mapping and exploration program spearheaded by Britain's Overseas Development Corporation, petroleum overshadowed interest and investment in mineral exploration. In the 1980s, however, in the context of the Latin American debt-crisis and reduced returns from oil, Ecuadorian leaders began promoting mineral development. ${ }^{2}$ This political and discursive shift towards mining was furthered by notions of Andean uniformity and ideas of geological equivalence with countries like Peru and Chile. Portraying the nation as mineral rich and largely unexplored, officials foregrounded reforms to mining laws and programs of geological mapping and exploration.

For the British geologists who began working in Ecuador beginning in the late 1960s, notions of Andean uniformity also resonated. Reflecting on the prospect of a geological aid program to Ecuador, British officials highlighted a need for British involvement in South America's resource sector, then dominated by US interests. As narrated in 1965 by the head of the UN Ecuador team, himself a British geologist keen to involve the British Geological Survey (BGS): "We are living in a very competitive world, and if the British Government wishes to 'sell' aid programmes then it has to be done by good salesmen." ${ }^{2 x}$ For officials at the BGS, a mapping program in Ecuador would also allow them to tap into financial and political resources from

${ }_{26}$ Quoted in Marco Erazo. 1962. "El Problema Minero en el Ecuador." Anales de la Universidad de Cuenca, $18(1)$, p. 5.

${ }^{27}$ As part of this campaign, Ecuador's Ministry of Natural Resources published a promotional pamphlet titled "Ecuador: No Solo Petroleo, Sino Tambien Minería (Not Just Oil, but Also Mining). See: IGS /OD/22/1/11, Archives of the British Geological Survey.

${ }_{28}$ Peter Fozzard (UN Ecuador) to Gordon Whittle (BGS), “Photogeological Aid: Ecuador," 10 July 1967.

IGS / OD / 22/1/1. Archives of the British Geological Survey. 
British Overseas Development. In his summation of the merits of working in Ecuador, the head of the BGS international division underpinned his assessments with notions of Andean equivalence- "the wide range of promising mineral occurrences known in Peru must almost certainly be repeated in Ecuador. The geology and mineral resources of Ecuador are largely unknown, and when the way is open for development it will be advantageous if a British connection in the field already exists."

Thus, for British geologists in the 1970s and Ecuadorian officials in the 1980s, Andean uniformity helped reinforce and justify programs of geological mapping and exploration. What I want to emphasize here is the way that plate-tectonic models of porphyry copper bolstered existing discourses and impressions of Andean homogeneity. Indeed, I would argue that platetectonic theory is a critical chapter in the story of and tensions between Andean symmetry and difference since the late $19^{\text {" }}$ century.

Porphyry copper refers to the low grade, high volume deposits that yield most of the world's copper. Mining porphyry copper emerged in the early $20^{\text {t }}$ century, when a young engineer named Daniel Jackling, who was inspired by the steam shovels working on the Panama Canal, devised a way to extract the low-grade copper that was previously seen as being of little value. By and large, the principle mines developed in the early $20^{\mathrm{m}}$ century were known sources of copper. These porphyry deposits were not discovered, therefore, but "were known to exist and their immense size was more than suspected," as AB Parsons describes in his 1930s account on the history of porphyry copper mining (Parsons 1956[1933]). Quite distinct from metaphors of discovery, Parsons relates the birth of the "Porphyries" as a story of "thawing" enormous quantities of known "frozen copper assets" (Parsons 1956:16-17); or, as the New York Times review of the book put it, "the creation of wealth where there was only waste rock before."

The iterations between geological discovery and porphyry copper shifted in the 1960s, when the exploration geologist David Lowell completed a systematic survey of the San ManuelKalamazoo copper ore body in southwestern Arizona, outlining, in turn, a general structure of these deposits. A 1970 publication in Economic Geology, published with J.M. Guilbert, produced what became known as the Lowell-Guilbert model (Lowell and Guilbert 1970). The LowellGuilbert model represents porphyry copper deposits as inverted raindrops that intrude into surrounding rock (Fig. 3). The brilliance behind Lowell's research was to show how separate copper deposits, the San Manuel and Kalamazoo, were actually the product of one original porphyry copper mineralization that had been subsequently separated and split by local geological faulting. The Lowell-Guilbert model gave mineral geologists a template from which they could re-construct assemblages of subsoil copper. As such, it "became a benchmark for the worldwide exploration industry." "What is noteworthy about the Lowell-Guilbert model is its

${ }^{2}$ David Bleakely. "Summary of visit to Peru and Ecuador," October 1967. IGS/OD/22/1/1. Archives of the British Geological Survey.

${ }^{30}$ New York Times, Book Review, 20 August 1933.

${ }^{31}$ Australian Academy of Science Newsletter. December 2009, p. 6. The Australian Academy of Science awarded Lowell the Haddon Forester King Medal for his contributions to mineral exploration, noting that, "Lowell has achieved worldwide fame as a practicing exploration geologist and lecturer. His field of specialty is porphyry copper deposits and his groundbreaking research and study with John Guilbert in 
hyper-local scale. It is an image of a copper deposit that is singular and isolated, an ideal type. It is not a model that differentiates copper formation at a regional scale, of and within the US southwest, for example (as Lowell (1975) sought to do in a later publication). Nor is it a model that outlines the economic viability of particular sites of mineralization.
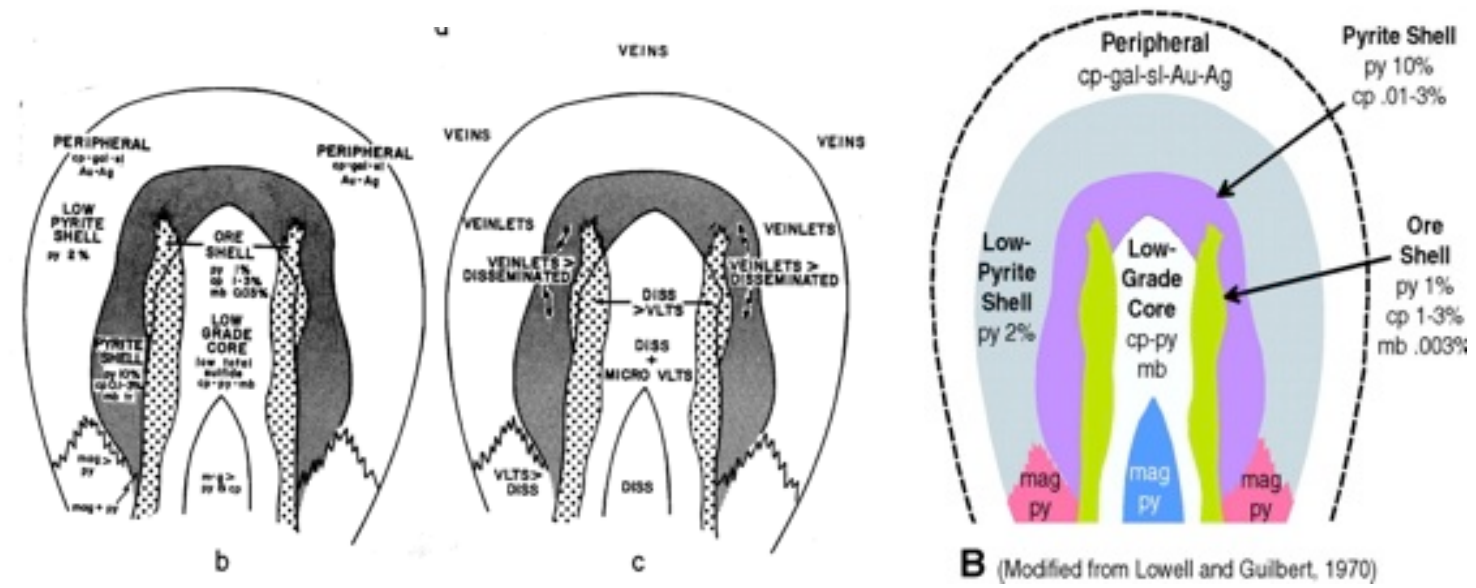

Figure 3: Iterations of the Lowell-Guilbert Model (Lowell and Guilbert 1970; Mars and Rowan 2006).

In 1972, Richard Sillitoe, a UK geologist, published a seminal paper relating the origin of porphyry copper to the theoretical paradigm of plate tectonics (Sillitoe 1972), dutifully titled "A Plate Tectonic Model for the Origin of Porphyry Copper Deposits." Highlighting known sources of porphyry copper, Sillitoe's work shows how copper mineralization, from the southern Andes to British Columbia, and throughout the entire Pacific Rim, is the result of the subduction of oceanic plates at continental margins. In the course of subduction, copper and water bearing crust melts and rises as buoyant, hot magma. Moving through crustal earth, the magma cools, forming large igneous intrusions called plutons within mountain terrain, usually at a depth of three to five kilometers from the surface. Under different regimes of pressure and temperature, as this magma cools, water present within the magma forms a hydrothermal solution that scavenges and concentrates copper from surrounding magma, depositing the copper-enriched material on the top ends of porphyry plutonic intrusions. Thus, porphyry copper deposits are mineral rich on the tops and outer edges of plutons, but the center is often barren of copper--which Lowell's work showed very clearly.

1967 set the scene for his future discoveries and became a benchmark for the global exploration industry in the search and discovery of new ore deposits." 


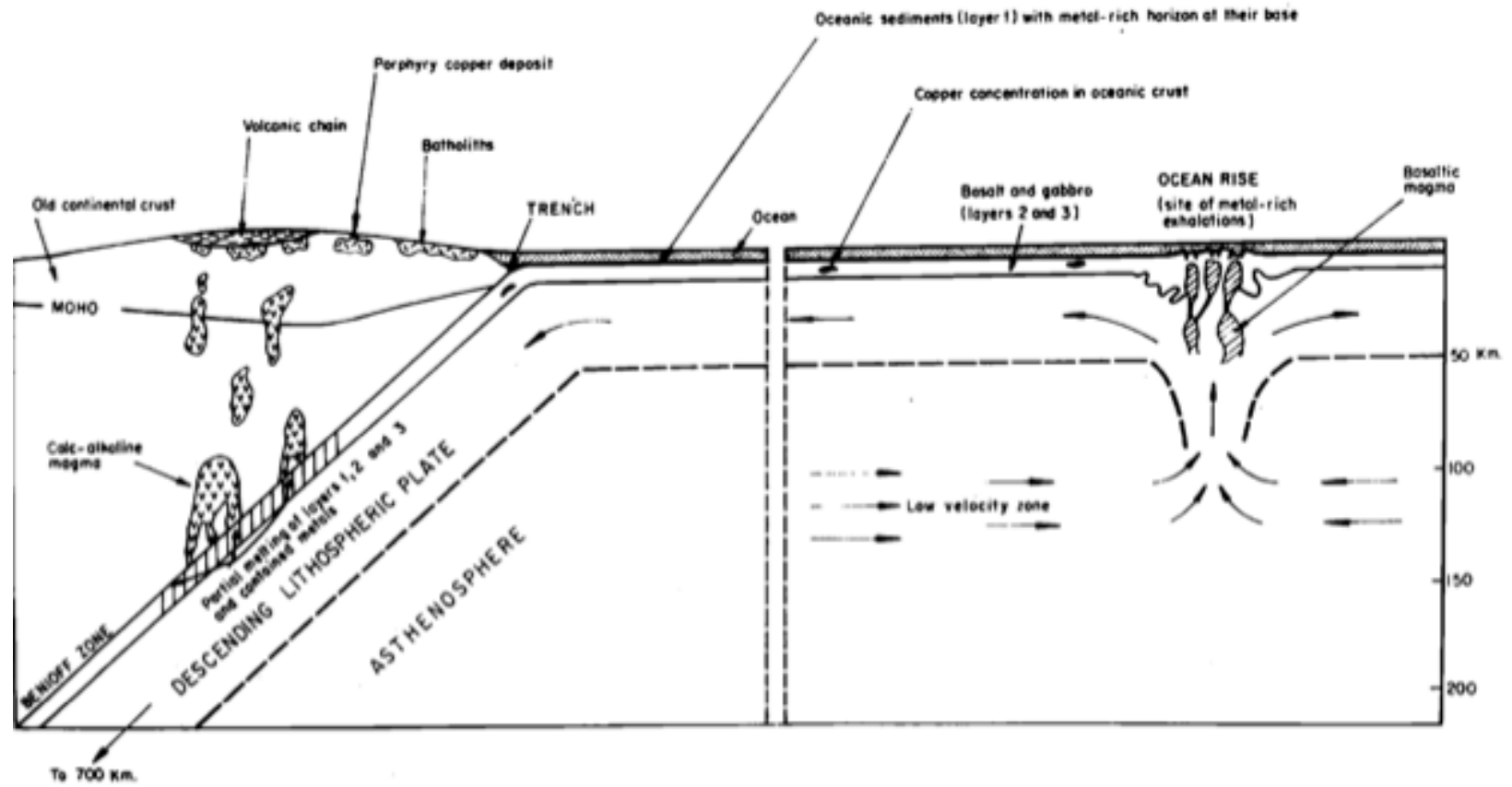

Figure 4: The Genesis of Porphyry Copper Deposits (Sillitoe 1972:188)

Whereas Lowell and Guilbert showed what specific porphyry copper deposits looked like, Sillitoe revealed the origin and creation story behind them. The Sillitoe framework helped make the Lowell-Guilbert model a global phenomenon. Taken together, Sillitoe's crude depiction of porphyry copper deposits, the rising blobs in Figure 4, then becomes the Lowell-Guilbert ideal type. The Lowell-Guilbert model is what comes into view when one zooms in on Sillitoe's image. The Sillitoe framework presents a global-scale origin story, while the Lowell-Guilbert model shows what these deposits might or should look like at a local level. Two other geologists, who applied Sillitoe's work in their model of a copper deposit in Chile, echoed this point, referring to porphyry copper deposits in the Andes as "variations on a common theme" (Gustafson and Hunt 1975:859)—an apt characterization of Andean resource equivalence.

These early formulations revealed unexplored areas with no prior history of copper mining, areas like Ecuador, to be potential sites of copper mineralization. The images in Figure 5, taken from Sillitoe's 1972 article, highlight the global relation between plate tectonics and the formation of porphyry copper. In doing so, they link the mineral resources in British Columbia with those in Chile. This image is, in Sillitoe's words, the Americas belt, which contains "most of the known porphyry copper deposits, [and] extends from western Argentina and central and northern Chile, through Peru, Ecuador, Panama, Mexico, the western United States, to British Columbia, the Yukon and Alaska" (Sillitoe 1972:185). Sillitoe's point is to show that copper deposits are "confined to orogenic belts characterized by calc-alkaline magmatism" (Sillitoe 
1972:187). Yet the continued evocation of copper belts, either the Andean belt or even Americas belt, highlights an underlying connection between existing copper mines and deposits. Belts are defined by notions of uniformity and presume the presence, or at least possibility, of subsoil copper.

Though Sillitoe presented broad connections between known copper mines in Chile, Peru, and the US southwest, Ecuador contributed in important ways. In the late 1960s, the United Nations mineral survey project identified an area of copper mineralization called Chaucha, along the southern end of Ecuador's western Andean range. At the time, Ecuadorian officials and British geologists were excited at the prospect that Chaucha represented a principal copper discovery "in the Andean belt outside of original producing areas [Chile, Peru]." exploration through the 1970s, however, showed limited copper content and the conclusion that that Chaucha was "sub-economic." Nevertheless, in his survey of linked copper sites along the Andes, Sillitoe included Chaucha as a point of reference, implying a degree of symmetry between copper in Chile and Ecuador as well as an underlying sense of possibility between them.
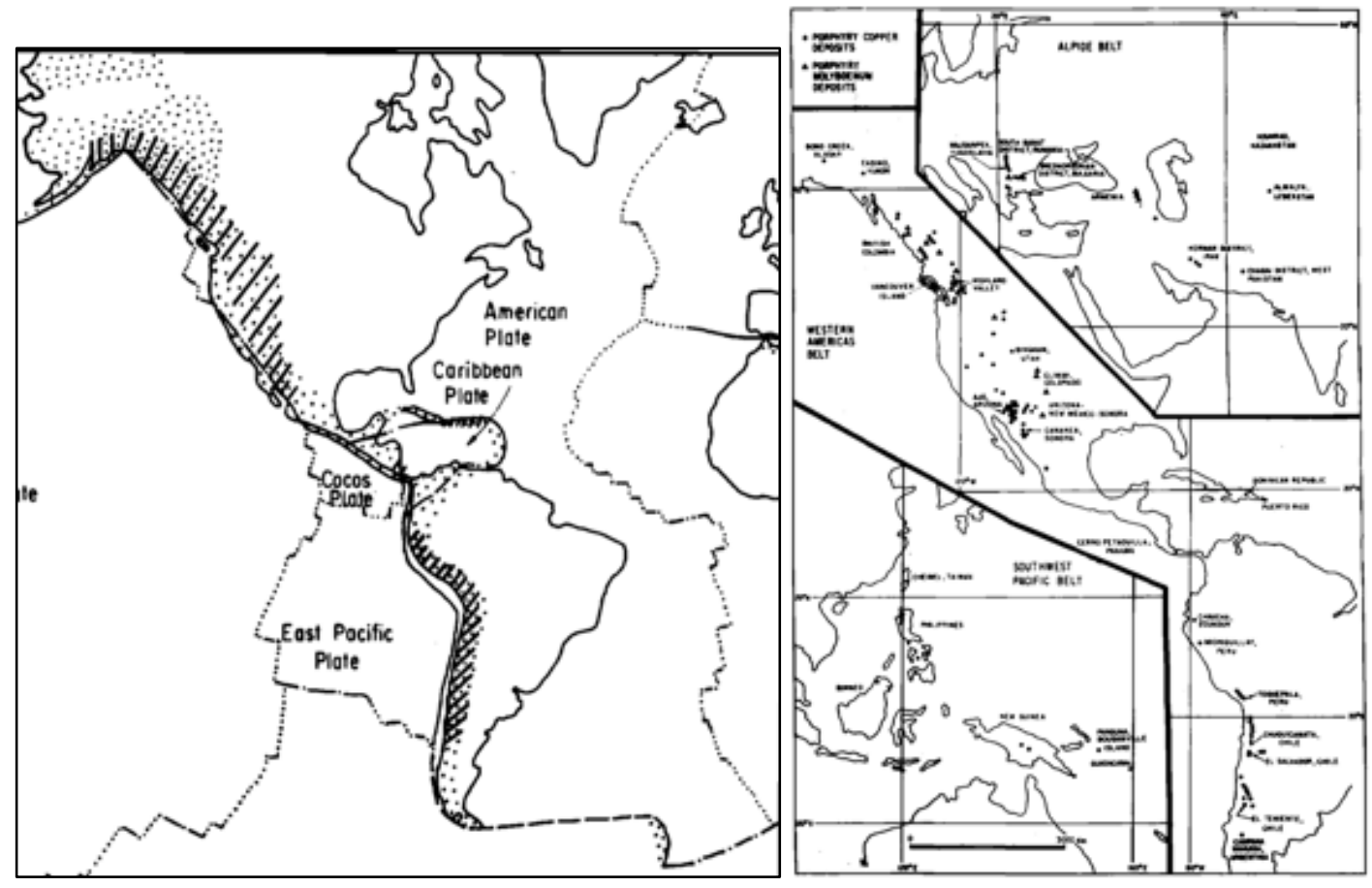

Figure 5: Porphyry Copper Belts in the Western Americas (Sillitoe 1972: 186, 187)

${ }_{32}$ David Bleakley, "Report on a visit to Chile, Peru, Ecuador, Trinidad and Jamaica," 12/69. IGS /OD/22/1/2. Archives of the British Geological Survey. 
The case of Chaucha reflects my broader point about the dialectics between nature and natural resources. Exploration at Chaucha was unsuccessful in outlining a mineral resource of economic value. The prospect of mineralization, however, was productive of frameworks of Andean nature that positioned Ecuador as a country of resource potential. Whereas prevailing analyses of resource becoming outline an inchoate process of natural resources emerging from nature, the partial demarcation of natural resources at Chaucha helped reinforce a specter of nature defined by Andean symmetry. By connecting these points on a map, the very nature of Sillitoe's model suggests a degree of equivalence between these sites. Even as it hinges around areas of copper mineralization, the plate-tectonic model is as much about the areas in-between.

From the 1960s to the 1980s, geological mapping in Ecuador shifted from extending the life-cycle of existing mines to being one structured by resource exploration and discovery. For British geologists, plate-tectonic models of porphyry copper energized and oriented this transition. The British team increasingly requested journal articles related to resource formation and plate-tectonic theory. At one point, the team even requested bringing on Richard Sillitoe as a short-term consultant. ${ }^{35}$ They likewise approached other sites of copper mineralization with the expectation of finding economically significant deposits. As head of the BGS overseas division wrote to Ecuador's team leader in 1977, "I am glad to note that you are taking a hard look at all those anomalous areas; perhaps the new one, Chaso Juan, will be the bonanza!" Like Chacha and others, however, Chaso Juan was sub-economic. A sense of Andean comparison and expectation also characterizes a letter from a British engineer to the British team in 1975: "It seems a pity that so far no real large Ore Body has been established in Ecuador when Peru and Chile are so well endowed." ${ }^{*}$

The models of porphyry copper genesis and structure, as articulated by Lowell and Sillitoe, share important traits with iconic Andean imagery from the 19 century. Like Church's Heart of the Andes, the models of copper detailed by Lowell, and mobilized by Sillitoe, are less about models of specific locations, but rather generalized processes and blueprints. They are ideal types: "the subtle essence of many scenes combined into a typical picture...all earth's riches compacted into one many-sided crystal," to borrow the language related to Heart of the Andes (Winthrop 1859:12). Both Heart of the Andes and plate tectonic models are floating signifiers of resource wealth. Church's paintings and Lowell's model of porphyry copper (seen within plate tectonic theory) are both about essence. Both strive to capture an underlying truth, expectation, and archetype about the nature of copper and the nature of the Andes. Even as the Sillitoe framework provides a broad-based scale in which the Lowell-Guilbert model can circulate, it likewise shares a nowhere/everywhere dialectic of resource potential. The image of plate subduction in figure 4 presents a basic outline of Andean mineralization that exists nowhere in particular (this could be Chile; it could be Ecuador), but is potentially located anywhere along the Andean range.

${ }^{33}$ JW Baldock to David Bleakley, 11/29/78. IGS/OD/22/1/9. Archives of the British Geological Survey. ${ }^{34}$ Sir John Wrightson to Sir Kingsley Dunham, 4/7/75. IGS/OD/22/1/5. Archives of the British Geological Survey. 
The original Sillitoe model of porphyry copper, in equating copper genesis with ubiquitous processes of plate subduction, presented a global picture of mineral possibility. While building on this scholarship, economic geologists have recently emphasized the particular and extraordinary factors that go into the formation of porphyry copper deposits. In a 2001 article, for example, geologist Mark Cloos takes aim at what he calls the simplified, "introductory textbook" version of porphyry copper--depicted only in relation to plate subduction. This image assumes that copper deposits should be abundant, when in fact, Cloos says, they are "very rare" (2001:288). Similarly, geologist J.P. Richards asserts that more attention should be paid to the variability of tectonic processes along the broad arcs of plate subduction. Emphasizing "differential stress fields" and the "constant state of flux," Richards argues that "the default product [of plate subduction] is likely to be a barren or weakly mineralized" porphyry rock. It is only where "processes converge optimally" that economically significant copper deposits form (Richards 2003:1528). In defining the genesis of porphyry copper deposits, the phrase "converge optimally" reverses the language of expectation that has defined the promotion of Ecuador's mining industry. Indeed, Cloos and Richards highlight how exploration for copper is more likely to uncover "barren or weakly mineralized" (Richards 2003:1528) porphyry rock than it is to encounter rich and abundant porphyry copper deposits.

\section{Conclusion: Nature and Resource Becoming}

As I have outlined in this article, notions of Ecuadorian resource abundance rely on and substantiate certain perceptions of Andean nature over others-namely, ideas of uniformity and equivalence over Andean difference and heterogeneity. The potential becoming of Ecuador's subsoil as a repository of mineral wealth cannot be separated from the shifting ontology of the Andes occasioned by plate-tectonic theory, its validation of $19^{\text {th }}$ century Andean discourse, and their overlapping articulation within the promotion of mining over the past three decades. As I have also demonstrated, contemporary claims of Ecuadorian mineral wealth are contingent upon silencing histories of mineral scarcity, presumptions of Andean difference, and Ecuador's own history of marginal mining and the knowledge of Ecuadorian subsoil that it engendered. Notions of Andean uniformity also help engender floating signifiers of resource potential, the local/general and nowhere/ everywhere models of resource presence that feature prominently in Ecuador's promotion of mineral exploration.

Despite the branding of "Ecuador: Mining Country," Ecuador is not a mining country. Outside of a few small- and medium-scale mining projects in the southern part of the country, the only other sites of mineral potential are highly uncertain. In light of the repeated "false dawns" over the past three decades, as well as prior assessments of resource scarcity, it would be disingenuous to take Ecuador's claims of "unexplored abundance" for granted and simply as a question of time. Instead, the conjuring of resources that are both rich and unknown asks us to think about the shifting frames of knowledge and nature that inform this rendition of the nation's subsoil. In outlining the connection between ideas of Andean nature and Ecuadorian resource potential, I have shown some of the broader and taken-for-granted frames of reference that 
underpin the very becoming of the subsoil as a locus of resource wealth. In doing so, I have highlighted the ways in which articulations of the Andes underpin the continual resetting of Ecuadorian mineral exploration over the past three decades. Notions of Andean uniformity and resource abundance continue to provide a reservoir of truth that justifies programs of resource exploration. Assessments of Ecuador's potential as a "mining country" of global standing are less about identifiable economic deposits across the country and more about an underlying national geo-body that transcends what is known of Ecuador's subsoil. Indeed, there is a fundamental contradiction in Ecuador's claim to being both "largely unexplored" and a "mining country" in the present and immediate future. Ecuador's promotion of mining, therefore, has been less about natural resources and more about nature, less about subsoil material that might emerge from across the country and impact aboveground social and political relations, and more about the ideas of nature that are indexed against particular Andean ontologies.

\section{Acknowledgements}

This article builds on research that was funded by the National Science Foundation (STS Doctoral Dissertation Research Improvement Grant, 0925447), the Yale MacMillan Center Dissertation Research Grant, and the Yale Tropical Resources Institute. I am grateful to the editors of ESTS and the anonymous reviewer for their insightful feedback. I especially thank Abby Kinchy, Roopali Phadke, and Jessica Smith for their careful reviews of this article and for their efforts in convening the productive STS Underground workshop where I was able to share aspects of this article with scholars pursuing similar questions. I also thank Trevor Birkenholtz, Robyn d'Avignon, and Adrianne Kroepsch for their invaluable suggestions on earlier drafts.

\section{Author Biography}

David Kneas is an assistant professor in the Department of Geography and School of Earth, Ocean, and Environment at the University of South Carolina. His research interests center on the cultural politics of nature in the Americas. He has conducted long-term ethnographic and historical research in the Intag region of northwestern Ecuador, research that situates the

contemporary conflict over proposed copper mining within regional histories of agrarian settlement and national histories of mineral exploration.

\section{References}

Bain, H. Foster. 1934. Ores and Industry in South America. New York: Harper Brothers.

Bakker, Karen, and Gavin Bridge. 2006 "Material Worlds? Resource Geographies and the 'Matter of Nature."' Progress in Human Geography 30(1):5-27.

Barry, Andrew. 2013. Material Politics: Disputes along the Pipeline. Oxford: Wiley-Blackwell.

Bennett, Jane. 2010. Vibrant Matter: A Political Ecology of Things. Durham, NC: Duke University Press. 
Bowden, Gary. 1985. "The Social Construction of Validity in Estimates of US Crude Oil Reserves." Social Studies of Science 15(2): 207-240.

Bridge, Gavin. 2009. "Material Worlds: Natural Resources, Resource Geography and the Material Economy." Geography Compass 3(3):1217-1244.

Bridge, Gavin. 2001. "Resource triumphalism: postindustrial narratives of primary commodity production." Environment and Planning A 33: 2149-2173.

Chapman, Chelsea. 2013. Multinational Resources: Ontologies of Energy and the Politics of Inevitability in Alaska. In Cultures of Energy: Power, Practices, Technologies, edited by S. Strauss, S. Rupp, and T. Love, 96-109. Walnut Creek, CA: Left Coast Press.

Cloos, Mark. 2001 "Bubbling Magma Chambers, Cupolas, and Porphyry Copper Deposits." International Geology Review 43(4):285-311.

DeGregori, Thomas R. 1987. "Resources Are Not; They Become: An Institutional Theory." Journal of Economic Issues 21(3):1241-1263.

Ferry, Elizabeth Emma. 2005. "Geologies of Power: Value Transformations of Mineral Specimens from Guanajuato, Mexico." American Ethnologist 93(3):420-436.

Frederiksen, Tomas. 2013. "Seeing the Copperbelt: Science, mining and colonial power in Northern Rhodesia." Geoforum 44: 271-281.

Frickel, Scott and Abby Kinchy. 2015, "Lost in space: geographies of ignorance in science and technology studies." IN Routledge International Handbook of Ignorance Studies, edited by M. Gröss and L McGoey, 174-182. New York: Routledge.

Graeber, David. 2015. "Radical alterity is just another way of saying "reality" A reply to Eduardo Viveiros de Castro." Hau: Journal of Ethnographic Theory 5 (2):1-41

Gustafson, Lewis and John Hunt. 1975. "The Porphyry Copper Deposit at E1 Salvador Chile." Economic Geology 70(5):857-912.

Hess, David. 2016. Undone Science: Social Movements, Mobilized Publics, and Industrial Transitions. Cambridge, MA: MIT Press.

Higgins, W.G. 1900. “The Mineral Industry of Ecuador, South America." Transactions of The Institute of Mining Engineers 18:515.

Huber, Matthew T. 2013. Lifeblood: Oil, Freedom, and the Forces of Capitol. Minneapolis: University of Minnesota Press.

Hughes, David. 2017. Energy Without Conscience: Oil, Climate Change, and Complicity. Durham: Duke University Press.

Jones, Katherine. 1997. “Scale as epistemology.” Political Geography 17(1): 25-28.

Kaup, Brent. 2008. "Negotiating through nature: The resistant materiality and materiality of resistance in Bolivia's natural gas sector." Geoforum 39: 1734-1742.

Kneas, David. 2017. "Necessary Illusions: Fetishism and the becoming of subsoil resources." The Extractive Industries and Society 4: 846-851.

Kneas, David. 2016. "Subsoil Abundance and Surface Absence: A Junior Mining Company and its Performance of Prognosis in Northwestern Ecuador." Journal of the Royal Anthropological Institute 22(S1): 67- 86. 
Lowell, David and J.M. Guilbert. 1970. "Later and Vertical Alternation-Mineralization Zoning in Porphyry Ore Deposits." Economic Geology 65(4): 373-408.

Mars, John and Lawrence Rowan. 2006. "Regional mapping of phyllic- and argillic-altered rocks in the Zagros magmatic arc, Iran, using Advanced Spaceborne Thermal Emission and Reflection Radiometer (ASTER) data and logical operator algorithms." Geosphere 2(3): 161-186.

Mehlman, Jeffrey. 1972. “The 'Floating Signifier': From Lévi-Strauss to Lacan." Yale French Studies 48: 10-37.

Mercer, J.W. 1919. "Mining in Ecuador." Proceedings of the Second Pan American Scientific Congress: Volume VIII. Washington DC: Government Printing Office.

Miller, Benjamin and Joseph Singewald. 1919. The Mineral Deposits of South America. New York: McGraw Hill.

Mitchell, Timothy. 2009. “Carbon Democracy." Economy and Society 38(3):399-432.

Orlove, Ben. 1993, "Putting Race in its Place: Order in Colonial and Postcolonial Peruvian Geography." Social Research 60(2): 301-336.

Orton, James. 1870. The Andes and the Amazon; or, Across the Continent of South America. New York: Harper Brothers.

Parsons, AB. 1956[1933]. The Porphyry Coppers. New York: The Maple Press Company.

Poole, Deborah. 1997. Vision, Race, and Modernity: A Visual Economy of the Andean Image World. Princeton, NJ: Princeton University Press.

Poole, Deborah 1998. "Landscape and the Imperial Subject: U.S. Images of the Andes, 1859-1930." In Close Encounters of Empire: Writing the Cultural History of US-Latin American Relations, edited by G. Joseph, C. LeGrande, and R. Salvatore, 107-138. Durham, NC: Duke University Press.

Pratt, Mary Louise. 1992. Imperial Eyes: Travel Writing and Transculturation. New York: Routledge.

Pritchett, James. 1860. "Explorations in Ecuador in the Years 1856 and 1857." Journal of the Royal Geographical Society of London 30: 64-75.

Richards, JP. 2003. “Tectono-Magmatic Precursors for Porphyry Cu (Mo-Au) Deposit Formation," Economic Geology 98: 1515-1533.

Richardson, Tanya and Gisa Weszkalnys. 2014. "Resource Materialities." Anthropological Quarterly 87(1): 5-30.

Salvatore, Ricardo. 1998. "The Enterprise of Knowledge: Representational Machines of Informal Empire." In Close Encounters of Empire: Writing the Cultural History of US-Latin American Relations, edited by G. Joseph, C. LeGrande, and R. Salvatore, 69-104. Durham, NC: Duke University Press.

Scott, James C. 1998. Seeing Like a State: How Certain Schemes to Improve the Human Condition Have Failed. New Haven: Yale University Press.

Sillitoe, Richard. 1972. "A Plate Tectonic Model for the Origin of Porphyry Copper Deposits." Economic Geology 67(2): 184-197.

Stepan, Nancy. 2001. Picturing Tropical Nature. London: Reaktion Books.

Stoll, WC. 1962. “Notes on the Mineral Resources of Ecuador.” Economic Geology 57: 799-808. 
Tsing, Anna. 2000. “Inside the Economy of Appearances." Public Culture 12(1):115-44.

Walsh, Andrew. 2010. "The Commodification of Fetishes: Telling the Difference Between Natural and Synthetic Sapphires." American Ethnologist 37(1):98-114.

Winthrop, Theodore. 1859. A Companion Guide to the Heart of the Andes. New York: D Appleton \& Company.

World Bank. 1993. Ecuador: Mining Development and Environmental Control Technical Assistance Project. Washington, D.C.: The World Bank. 